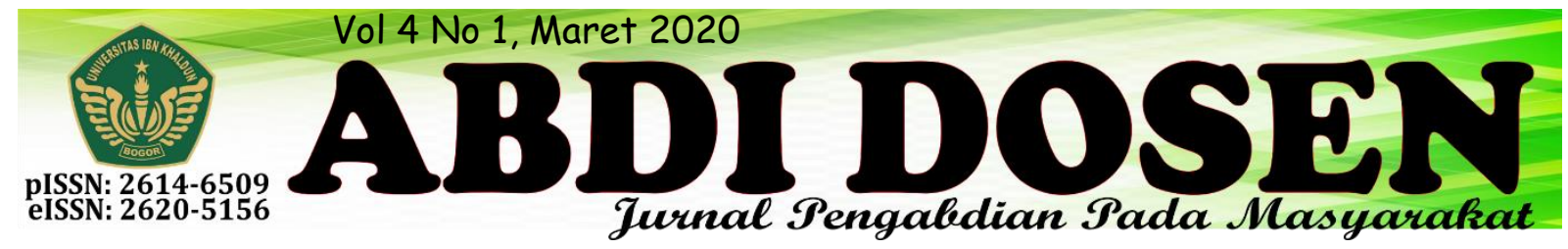

\title{
PENINGKATAN DAN PEMBERDAYAAN SUMBER DAYA MANUSIA SERTA PENGELOLAAN POTENSI DESA DALAM BERBAGAI BIDANG DI DESA PURASEDA
}

\author{
Widhi Ariyo Bimo ${ }^{1}$, Retno Triwoelandari ${ }^{2}$, Muhammad Nurul, Novia Indah Fitriyani ${ }^{3}$ \\ widhitambeh@gmail.com ${ }^{1}$ \\ $\underline{\text { retnotriwoelandari@uika-bogor.ac.id }}^{2}$ \\ muhamadnuru1001@gmail.com ${ }^{3}$ \\ nindahft@gmail.com ${ }^{3}$
}

Dosen Fakultas Ekonomi dan Bisnis ${ }^{1}$, Dosen Fakultas Agama Islam², Mahasiswa KKN Kelompok 19\&20 Tahun $2019^{3}$.

\begin{abstract}
ABSTRAK
Penelitian ini bertujuan untuk mengetahui maksud dari pembangunan yang ada di Indonesia yang ditujukan kepada semua bidang, tanpa terkecuali bidang kesehatan, pendidikan, ekonomi, kelembagaan, dan pemberdayaan lingkungan. Hal ini belum sepenuhnya mampu dipenuhi oleh pemerintah secara optimal dan maksimal. Universitas Ibn Khaldun Bogor (UIKA) sebagai salah satu lembaga pendidikan yang berada di kawasan Kota Bogor memiliki kewajiban untuk berperan serta secara aktif dalam pembangunan pada berbagai bidang tersebut. Kecamatan Leuwiliang sebagai salah satu kecamatan yang berada di Kabupaten Bogor dengan luas wilayah (-+) 61,77 H terdiri dari 13 Desa, dengan jumlah penduduk yang tercatat pada tahun 2017 adalah (-+) 122.352 Jiwa. Metode pengumpulan data yang digunakan oleh peneliti adalah metode observasi, untuk menganalisis data, peneliti menggunakan metode kualitatif yang disajikan dalam bentuk narasi. Subjek dalampenelitian ini yaitu warga Desa Puraseda Kecamatan Leuwiliang Kabupaten Bogor khususnya warga Kampung Sabrang RT 01 RW 10. Populasi yang ada yaitu semua warga Kampung Sabrang. Peneliti telah melaksanakan program untuk Bidang Pendidikan : 1) Mengajar di sekolah, 2) Bimbingan belajar. Bidang Ekonomi : 1) Kegiatan sosialisasi gemar menabung sejak dini, 2) Kegiatan sosialisasi hasil kerajinan tangan, 3) Seminar edukasi pasar modal syari'ah. Bidang Lingkungan: 1) Seminar pilah sampah menjadi rupiah, 2) Optimalisasi potensi desa, 3) Meningkatkan infrastruktur desa, 4) Renovasi sarana pendidikan. BidangKesehatan : 1) Penyuluhan dan praktek PHBS, 2) Kegiatan kerja bakti, 3) Kegiatan senam dan cek kesehatan. Bidang Hukum: 1) Seminar penyuluhan hukum.
\end{abstract}

\section{Kata Kunci : Kuliah Kerja Nyata, Masyarakat, Program Kerja}

\section{PENDAHULUAN}

Program Kuliah Kerja Nyata (KKN) adalah suatu bentuk pendidikan dalam bentuk pengabdian kepada masyarakat. Dalam bentuk pengabdian ini mahasiswa diberikan pengalaman belajar untuk hidup di tengah - tengah masyarakat diluar kampus dan secara langsung mengidentifikasi serta menangani masalah - masalah pembangunan yang dihadapi.Universitas Ibn Khaldun Bogor 
(UIKA) sebagai salah satu lembaga pendidikan yang berada di Kota Bogor yang memiliki kewajiban untuk berperan aktif dalam pembangunan di bidang kelembagaan seperti pendidikan, kesehatan, ekonomi, serta pemberdayaan lingkungan peran tersebut tidak hanya dilakukan oleh mahasiswa saja, akan tetapi juga dilakukan oleh masyarakat luas. Salah satu bentuk peran aktif yang dilakukan adalah dengan diadakannya Kuliah Kerja Nyata (KKN) tematik terintegrasi yang diselenggarakan oleh Lembaga Penelitian dan Pengabdian Masyarakat (LPPM) UIKA dan dilaksanakan oleh mahasiswa UIKA di Desa Puraseda di Kecamatan Lewiliang Kabupaten Bogor.

$$
\text { Kuliah Kerja Nyata (KKN) }
$$

Universitas Ibn Khaldun Bogor merupakan salah satu implikasi dari Tri Dharma Perguruan Tinggi yaitu pengabdian masyarakat. KKN bagi mahasiswa diharapkan dapat menjadi suatu pengalaman belajar yang baru untuk menambah pengetahuan, kemampuan, dan kesadaran hidup bermasyarakat. Kehadiran mahasiswa diharapkan mampu memberikan motivasi dan inovasi dalam bidang pembangunan.

Kecamatan Lewiliang merupakan salah satu kecamatan yang ada di Kabupaten Bogor dengan luas wilayah kurang lebih $61,77 \mathrm{H}$ yang terdiri dari 13 desa, dengan jumlah penduduk yang tercatat pada tahun 2017 adalah kurang lebih 122.352 jiwa. Secara demografis Desa Puraseda memiliki banyak potensi diantaranya bidang wisata curug, dan bidang pertanian yang dapat dioptimalkan dalam usaha untuk pembangunan desa dan meningkatkan perekonomian masyarakat Desa Puraseda. Akan tetapi, kenyataannya yang didapat dilapangan berbagai potensi tersebut selama ini belum dapat dioptimalkan dengan baik oleh masyarakat. Untuk mendukung hal tersebut perlu juga dilakukan peningkatan di bidang kesehatan dan pendidikan sebagai dasar terbentuknya SDM yang berkualitas dan berpotensi agar terciptanya sumber daya masyarakat yang lebih baik.

Berdasarkan permasalahan diatas, dilakukan program oleh tim Kuliah Kerja Nyata (KKN) Desa Puraseda Kecamatan Lewiliang Kabupaten Bogor sebagai salah satu upaya untuk mengoptimalisasikan potensi yang ada di Desa Puraseda.

\section{Demografi}

\section{Letak Geografis}

Desa Puraseda luas wilayahnya 390,440 Ha, terdiri dari 12 RW,32 RT dan 4 Dusun. Yaitu Dusun 1-2 dan Dusun 3-4, dengan batas-batas wilayah sebagai berikut:

\begin{tabular}{|l|l|}
\hline \multicolumn{1}{|c|}{ Batas } & \multicolumn{1}{c|}{ Desa } \\
\hline Sebelah Utara & Karyasari \\
\hline Sebelah Selatan & Bantar Karet \\
\hline Sebelah Timur & Purasari \\
\hline Sebelah Barat & Pabangbon \\
\hline \multicolumn{1}{|c|}{ Jarak dari $\quad$ Desa Puraseda ke }
\end{tabular}

Kecamatan Leuwiliang11 Km, jarak ke Kabupaten Bogor $40 \mathrm{Km}$, jarak ke Ibu Kota Provinsi di Bandung $120 \mathrm{Km}$ dan jarak ke Ibu Kota Negara di Jakarta 60 Km. Secara Visualisasi, wilayah administratif dapat dilihat dalam peta wilayah Desa Puraseda sebagai berikut:

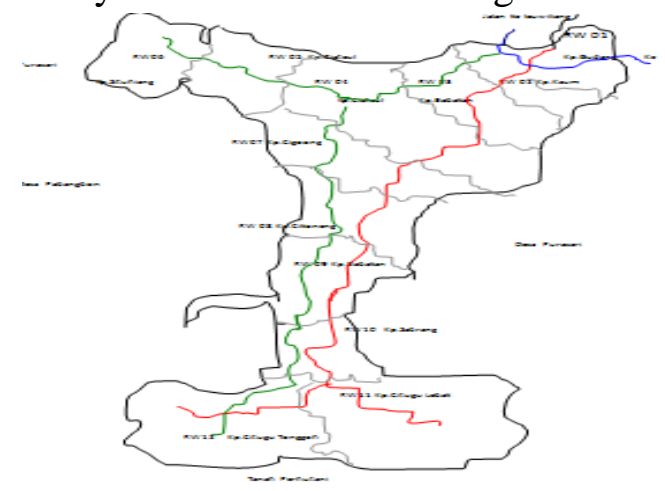




\section{Topografi}

Desa Puraseda merupakan desa yang berada didaerah dataran rendah, dengan ketinggian 600-700 meter diatas permukaan laut (mdpl). Sebagian besar wilayah desa adalah lahan pesawahan dan pemukiman dan kemiringanperbukitan antara $20^{\circ}-45^{0}$.Suhu rata-rata harian mencapai $30-42^{\circ} \mathrm{C}$.

\section{METODE}

Metode yang dilakukan pada penelitian ini yaitu menggunakan metode observasi. Kriyantono, (2006: 110-111); dan Bungin, (2011: 121) mendefinisikan observasi sebagai suatu proses melakukan pemilihan, pengubahan, pencatatan, dan pengkodeaan serangkaian perilaku dan suasana berkenaan dengan organisme in situ, sesuai dengan tujuan-tujuan empiris.Weick (1976: 253) secara lebih dalam menyebutkan bahwa observasi tidak hanya meliputi prinsip kerja sederhana, melainkan memilik karakteristik yang begitu komplek. Terdapat tujuh karakteristik dalam kegiatan observasi, dan selanjutnya menjadi proses tahapan observasi. Tahapan atau proses observasi tersebut meliputi pemilihan (selection),pengubahan (provocation), pencatatan (recording), dan pengkodeaan (encoding), rangkaian perilaku dan suasana (tests of behavior setting), in situ, dan untuk tujuan empiris..Jadi, dapat dikatakan bahwa observasi adalah salah satu metode pengumpulan data dengan mengamati atau meninjau secara cermat dan langsung

\section{HASIL DAN PEMBAHASAN}

\section{A. BIDANG PENDIDIKAN}

Dalam divisi pendidikan kami terdiri dari 9 orang mahasiswa yang berasal dari Fakultas Keguruan dan Ilmu

\section{Kependudukan}

Penduduk Desa Puraseda berdasarkan data terakhir hasil sensus Penduduk Tahun 2016 tercatat sebanyak 7532 jiwa, Tahun 2015 sebanyak 7547 Jiwa, dan Tahun 2014sebanyak 7660 Jiwa, Sehingga mengenai pendudukDesa Puraseda mengalami kenaikan untuk setiap tahunnya.

dilokasi penelitian untuk mengetahui secara langsung kondisi yang terjadi untuk membuktikan kebenaran dari sebuah desain penelitian. Observasi ini dilakukan selama Kuliah Kerja Nyata (KKN).

Penelitian ini sudah dilaksanakan dari tanggal 6 Agustus 2019 sampai 6 September 2019. Subjek penelitian ini adalah Desa Puraseda Kampung Sabrang RT 01 RW 10 Kecamatan Lewiliang Kabupaten Bogor. Adapun teknik pengumpulan data yaitu dengan cara observasi. Observasi dalam penelitian ini dilakukan oleh seluruh Mahasiswa kelompok 19 dan 20 di Desa Puraseda. Observasi dalam penelitian ini adalah observasi secaralangsung , kemudian mencatat keadaan yang ada dimasyarakat sekitar. Observasi dilakukan selama proses kegiatan program Kuliah Kerja Nyata (KKN) berlangsung dari awal hingga akhir. Dalam observasi ini peneliti lebih banyak menggunakan observasi lapangan. Observasi akan lebih efektif apabila informasi yang hendak diambil berupa kondisi atau fakta alami.

Pendidikan (FKIP) dan Fakultas Agama Islam (FAI). Kami membantu mengajar di SDN Riung Gunung , PAUD Baitul Hikmah, Sekolah Diniyah Siqoyatul 
Hidayah, Bimbingan Belajar, serta mengadakan pojok baca dan seminar pendidikan untuk para guru yang mengajar tingkat SD, SMP, SMA di Desa Puraseda.
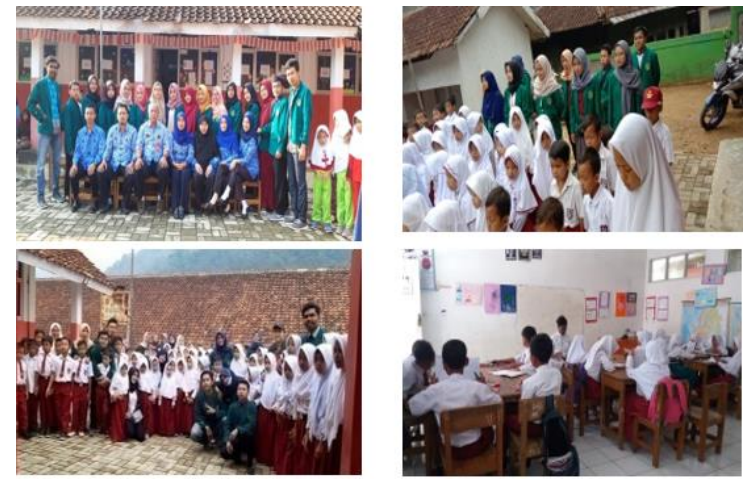

\section{Tenaga Pengajar}

Pada tanggal 13 Agustus 2019 sampai tanggal 28 Agustus 2019 setiap hari senin sampai dengan hari Rabu kami mengajar di SDN Riung Gunung dengan sebagian anggota kami yang berjumlah 6 orang mahasiswa. Jumlah siswa pada SDN Riung Gunung terdiri dari 130 siswa degan masing-masing kelas berjumlah 20 sampai 25 siswa. Pihak sekolah SDN Riung Gunung memberikan kepercayaan kepada kami untuk mengajar di setiap kelas, sehingga kami yang berjumlah 6 orang mendapatkan kesempatan untuk mengajar dengan sistem bergilir di setiap kelas. Kami mengajar berdasarkan kurikulum yang sudah ada di SDN Riung Gunung yaitu TEMATIK dengan menambahkan beberapa metode dan media dalam proses belajar mengajar di kelas. Salah satu metode yang digunakan adalah Pembelajaran Kooperatif. Pembelajaran Kooperatif adalah pembelajaran yang dilakukan secara berkelompok, siswa dalam satu kelas dijadikan kelompokkelompok kecil yang terdiri dari 4 sampai 5 orang untuk memahami konsep yang difasilitasi oleh guru (Slavin, 2008).ModelPembelajaran Kooperatif adalah model pembelajaran dimana siswa belajar secara kelompok dalam memecahkan sebuah masalah, yang didalam nya terdapat teknik diskusi dan tanya jawab. Dengan menggunakan Pembelajaran Kooperatif antusias siswa sangat terlihat dalam proses pembelajaran seperti melatih keberanian siswa dan kepercayaan dirinya untuk mengutarakan pendapatnya di depan kelas.
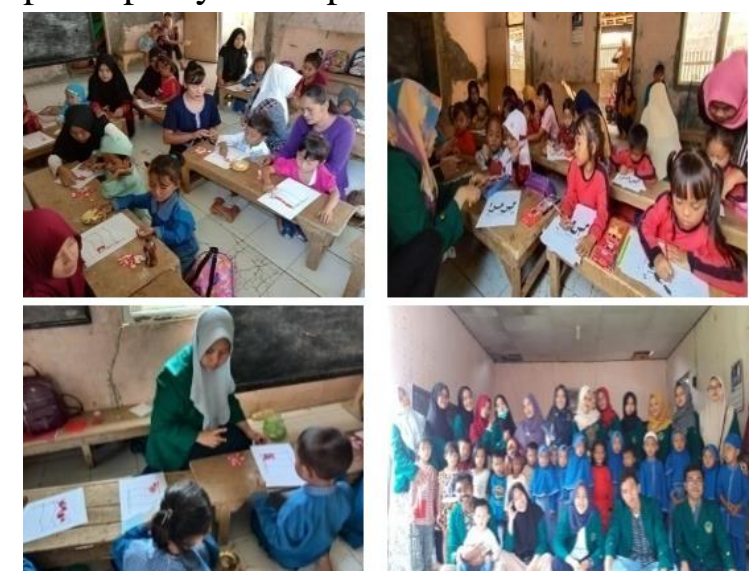

Selain kegiatan mengajar di SDN Riung Gunung 2 orang anggota divisi pendidikan membantu mengajar di PAUD Baitul Hikmah. Kegiatan belajar mengajar di PAUD Baitul Hikmah RW 10 di mulai dari tanggal 13 Agustus 2019 sampai tanggal 29 agustus 2019 setiap hari senin sampai dengan hari kamis. PAUD Baitul Hikmah terdiri dari 2 orang pegajar dan memiliki siswa yang berjumlah 26 orang, PAUD Baitul Hikmah masih belum memiliki izin untuk mendirikan lembaga pendidikan sehingga PAUD Baitul Hikmah menginduk pada PAUD Pelangi yang masih bertempat di Desa Puraseda RW 09. Proses kegiatan pembelajaran di PAUD Baitul Hikmah masih menggunakan media yang cukup sederhana, kegiatan tersebut seperti guru yang menulis di papan tulis dan siswa menyalinnya di buku masingmasing. PAUD Baitul Hikmah masih belum menggunakan kurikulum yang telah ditetapkan oleh pemerintah, tetapi tenaga pengajar di PAUD tersebut selaluberusaha memberikan pembelajaran yang dibutuhkan siswa seperti CALISTUNG. 
Dengan tidak adanya media pembelajaran serta buku pedoman di PAUD tersebut maka kami berusaha memberikan metode pembelajaran yang sebelumnya tidak pernah digunakan di PAUD Baitul Hikmah, seperti kegiatan merobek, menempel, mengenal bentuk geometri, mewarnai, belajar, bermain dan bernyanyi. Dari beberapa kegiatan pembelajaran yang telah disampaikan menimbulkan perubahan yang signifikan dalam proses pembelajaran di PAUD. Sehingga suasana proses pembelajaran menjadi lebih aktif dan menyenangkan. Sebagai pendukung proses pembelajaran di PAUD kami memberikan beberapa media pembelajaran seperti Flash Card, kertas origami dan beberapa buku panduan untuk mengajar.
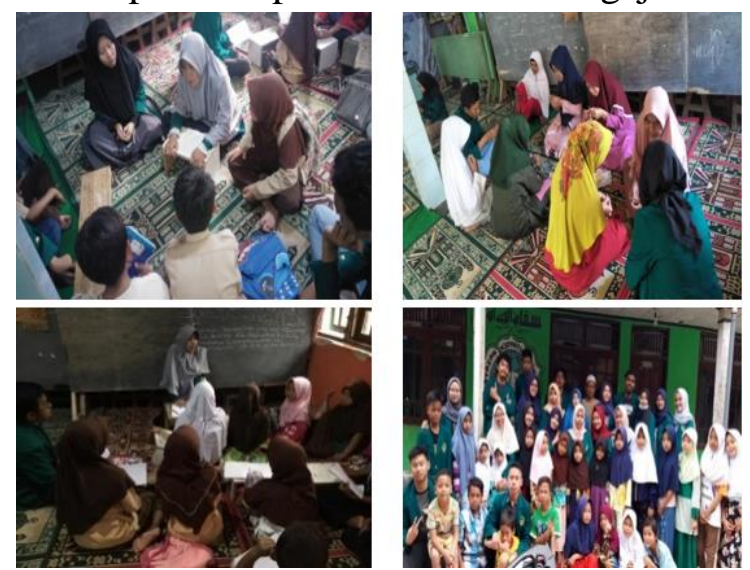

Selain di PAUD dan SD kami pun membantu mengajar di taman pendidikan islam yaitu Diniyah Takmiliyah Siqoyatul Hidayah. Di sekolah agama ini kami seluruh peserta KKN kelompok 19 dan 20 membantu pendampingan kegiatan belajar mengajar yang dilakukan setiap hari SeninSabtu pada pukul 13.00 hingga 15.00. Mengenai materi yang disampaikan adalah aqidah akhlak, al qur'an, hadits, tarikh islam, fiqih, dan bahasa arab. Dalam proses pembelajarannya kami menyesuaikan buku panduan yang telah disediakan, serta menambahkan sedikit metode yang bertujuan agar siswa dengan mudah memahami materi yang disampaikan.
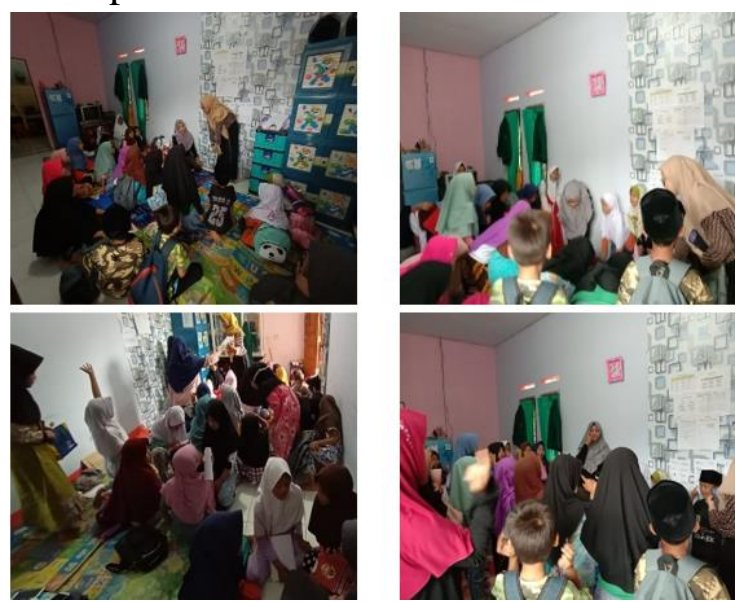

\section{Bimbingan Belajar (BIMBEL)}

Disamping itu, kami mengadakan kegiatan Bimbingan Belajar (BIMBEL) yang bertempat di POSKO kami, setiap hari Senin sampai Kamis pada pukul 16.00 hingga 17.00. Bimbingan beljaar yang kami berikan adalah pelajaran Matematika, Bahasa Arab, dan Bahasa Inggris. Antusisas warga terhadap adanya kegiatan BIMBEL ini sangat baik, dan banyak anak-anak yang mengikuti kegiatan ini setiap harinya. Sebagai penyemangat anakanak saat proses BIMBEL kami mengadakan games dan memberikan hadiah berupa snack ringan untuk menambah antusias belajar mereka.
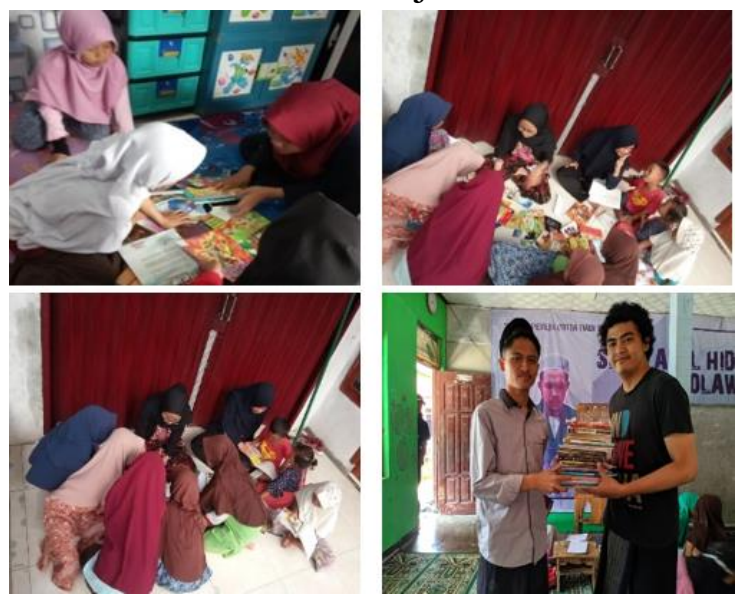

Program kerja selanjutnya adalah literasi dengan nama "Taman Bacaan". Kegiatan literasi ini adalah proses membaca buku bacaan seperti cerita nabi, 
novel, dan sebagainya. Setelah siswa membaca bukunya masing-masing kami melakukan sharing dan tanya jawab mengenai buku bacaan yang telah dibacanya. Kegiatan ini dilakukan setiap satu pekan sekali di hari Minggu sore, mengenai buku bacaan yang ada berasal dari pemberian mahasiswa KKN Kelompok 19-20. Selanjutnya, setelah kegiatan KKN berakhir buku yang kami berikan ditempatkan di Sekolah Diniyah sehingga diharapkan kegiatan ini akan terus berlanjut agar anak-anak memiliki minat baca yang tinggi.
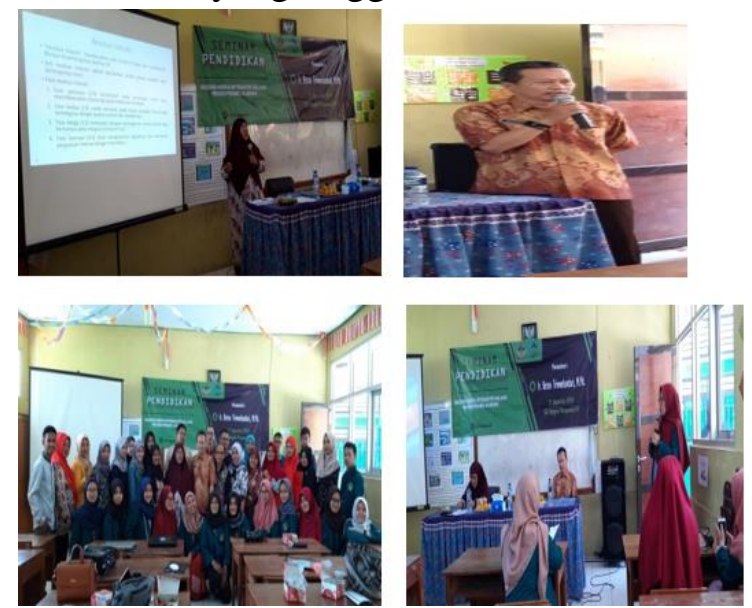

\section{Seminar Pendidikan}

Sebagai program kerja penutup kami mengadakan Seminar Pendidikan dengan tema "Urgensi media interaktif dalam proses pembelajaran”. Seminar ini diadakan berdasarkan kebutuhan tenaga pendidik di Desa Puraseda, dari hasil yang kami peroleh melalui penyebaran angket dan observasi pada setiap sekolah pada tingkatan SD, SMP, dan SMA sederajat. Kegiatan seminar pendidikan ini dilakukan pada hari Sabtu, 31 Agustus 2019 di SDN Puraseda 01 dengan pemateri Ir. Retno Triwoelandari, M.Pd. Dengan target peserta 55 orang dari setiap perwakilan sekolah yang ada di Desa Puraseda, namun peserta yang hadir pada kegiatan berjumlah 30 orang.

\section{B. BIDANG EKONOMI}

Dalam bidang ekonomi kami terdiri dari 8 orang mahasiswa yang berasal dari Fakultas Ekonomi dan Bisnis (Manajemen dan Akuntansi) dan Fakultas Agama Islam (Ekonomi Syariah)

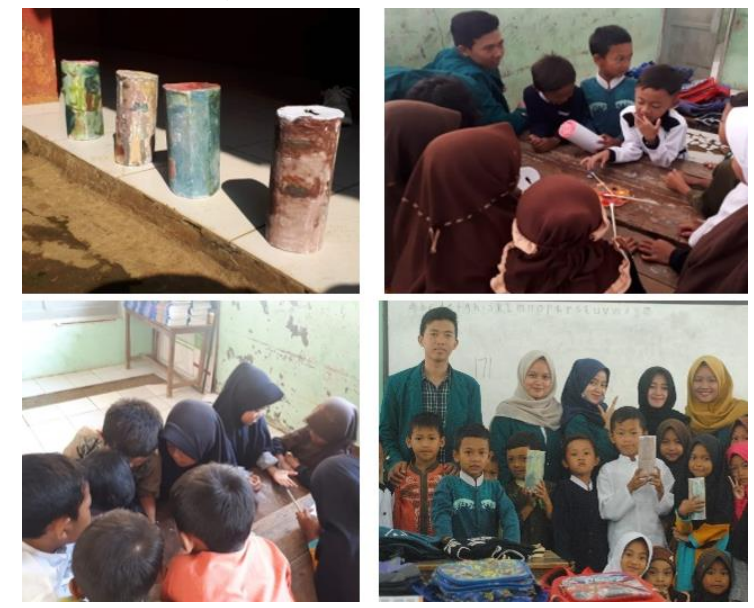

\section{Gerakan Menabung Sejak Dini}

Adapun program kerja yang telah terlaksana adalah Gerakan Menabung Sejak Dini yang dilaksanakan pada tanggal 22 Agustus 2019 di lingkungan SDN Riung Gunung. Kegiatan ini ditujukan kepada siswa dengan tujuan member edukasi pentingnya menabung serta praktik membuat celengan dengan memanfaatkan kardus bekas sebagai media utama dan juga kami menyediakan cat air kepada siswa untuk mengkreasikan celengannya masing-masing. Dari proker tersebut siswa sangat antusias dan senang sehingga tujuan yang kami rencanakan dapat berjalan dengan lancar.
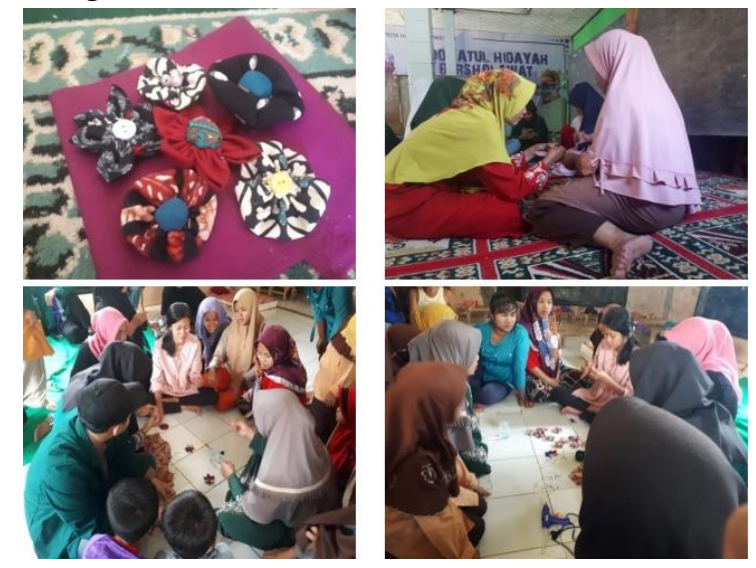

2. Ekonomi Kreatif 
Program kerja Ekonomi Kreatif (bross jilbab) telah terlaksana yang dilaksanakan pada tanggal 15 Agustus 2019 dan23 Agustus 2019 di lingkungan RT 01-02 RW 10. Proker ini termasuk proker jangka menengah atau mingguan. Tujuan proker ini adalah memanfaatkan barang yang tidak terpakai menjadi sesuatu yang bernilai jual, yaitu kain perca yang biasanya digunakan sebagai lap dapur atau bahkan dibuang. Disini kami berbagi sedikit ilmu dengan memberikan praktik kain perca yang sudah di pola berbentuk lingkaran dan persegi panjang yang kemudian dijahit menggunakan benang jahit yang pastinya dimiliki ibu-ibu dan tambahan kancing untuk memperindah bross tersebut serta tak lupa kami member edukasi tentang cara memasarkan produk mulai dari pengemasan berikut brand produk juga perhitungan modal dan laba yang nantinya di dapat. Kegiatan tersebut bermanfaat karena telah di praktikan kembali oleh ibu-ibu dirumah mereka, hal ini lah yang membuat kami senang karena apa yang telah disampaikan dapat di aplikasikan kembali secara langsung.
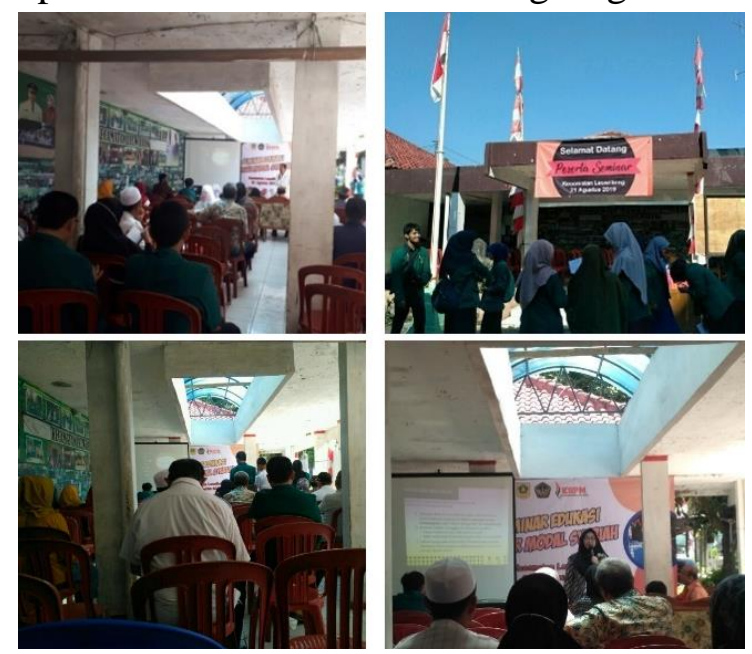

\section{Seminar Edukasi Pasar Modal Syariah}

Program Kerja selanjutnya adalah

Seminar Edukasi Pasar Modal Syariah yang dilaksanakan pada tanggal 21
Agustus 2019 di Kecamatan Leuwiliang. Seminar ini mencakup satu kecamatan dimana setiap desa yang ada di Leuwiliang di undang sebagai perwakilan dan perwakilan tersebut harus menyampaikan lagi edukasi yang di dapat kepada warga disetiap desa mereka. Acara ini langsung di bombing oleh Bpk. Widhi Ariyo Bimo, SE., MM. selaku dosen Fakultas Ekonomi dan Bisnis Universitas Ibn Khaldun Bogor dan kami juga bekerjasama dengan Bursa Efek Indonesia (BEI) sebagai pembicara pada seminar tersebut. Seminar ini memberikan informasi pentingnya berinvestasi secara syariah serta investasi yang tak selalu berbentuk tanah, emas, dll. Melainkan investasi berupa saham yang diperjualbelikan di pasar modal.

\section{DIVISI KESEHATAN}

Kami dari Divisi Kesehatan Fakultas Ilmu Kesehatan melakukan 4 Program. Yaitu kerja bakti, PHBS CTPS, Posyandu imunisasi \& cek kesehatan ibu hamil, dan senam sehat \&cek kesehatan.
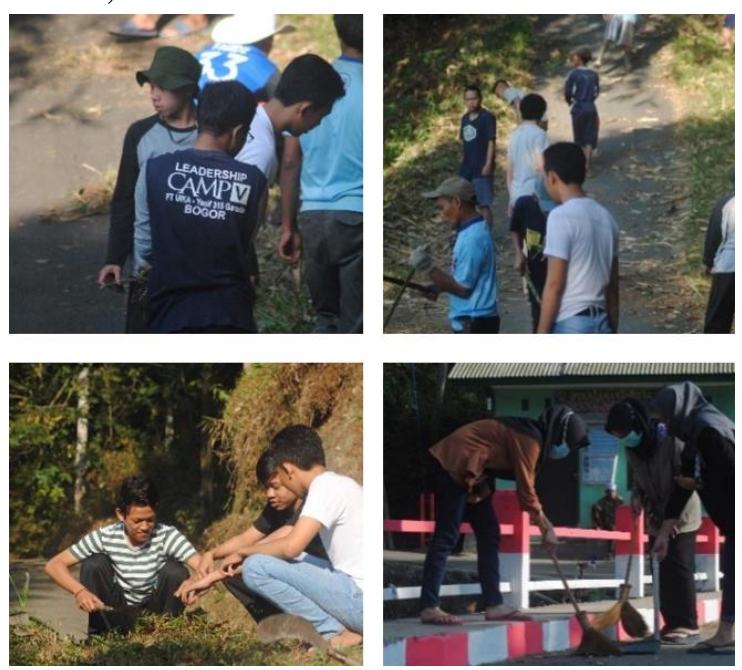

1. Kerja Bakti

Program pertama yang kami laksanakan adalah program kerja bakti yang mana program tersebut di laksanakan pada tanggal 9 Agustus 2019. Program tersebut dibantu oleh warga RW 10 yg dilakukan di sekitaran jalan RW 10. Kegiatan kerja bakti ini dilakukan pada 
pukul 07.00 sampai dengan selesai. Kerja bakti dilakukan guna membersihkan tepi jalan sekitar dari berbagai rumput liar dan sampah yg berserakan.
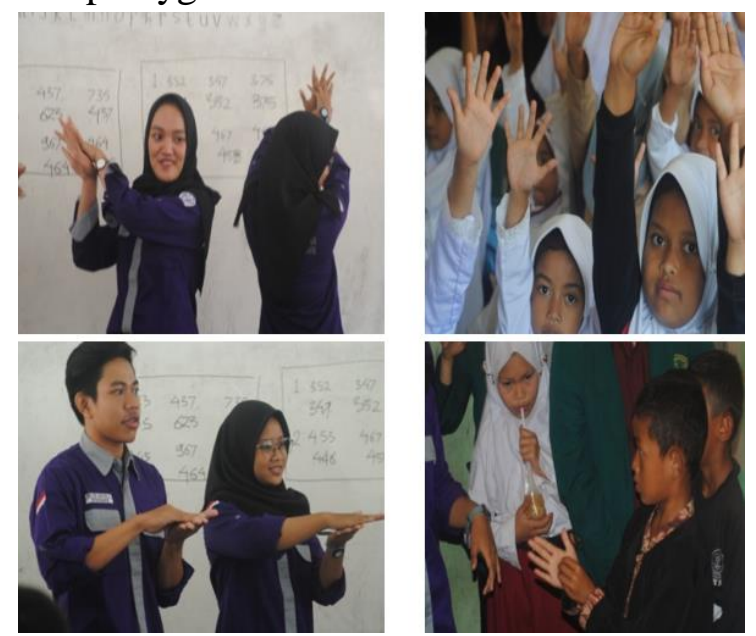

2. Perilaku Hidup Bersih dan Sehat (PHBS)

Program selanjutnya adalah penyuluhan kesehatan tentang Perilaku Hidup Bersih dan Sehat (PHBS) yaitu cara mencuci tangan yang baik dan benar pada tanggal 14 Agustus 2019. CTPS merupakan program kerja mahasiswa kesehatan masyarakat sebagai bentuk meningkatkan kesehatan pada anak dengan cara meningkatkan kesehatan personal hygiene. Program ini bertujuan untuk memberikan edukasi kepada siswa-siswi kelas 12 dan 3 serentak di SDN Riung Gunung agar mereka semua mengetahui cara cuci tangan yang baik dan benar sebelum mereka makan atau minum, penyuluhan cuci tangan PHBS yang kita lakukan menggunakan hand sanitizier karena disekolah Riung Gunung ketersediaan air yang sangat terbatas. Siswa-siswi kelas 1, 2, dan 3 sangat berantusias mengikuti serangkaian kegiatan penyuluhan cuci tangan yang dibarengi dengan nyanyian dan gerakan.
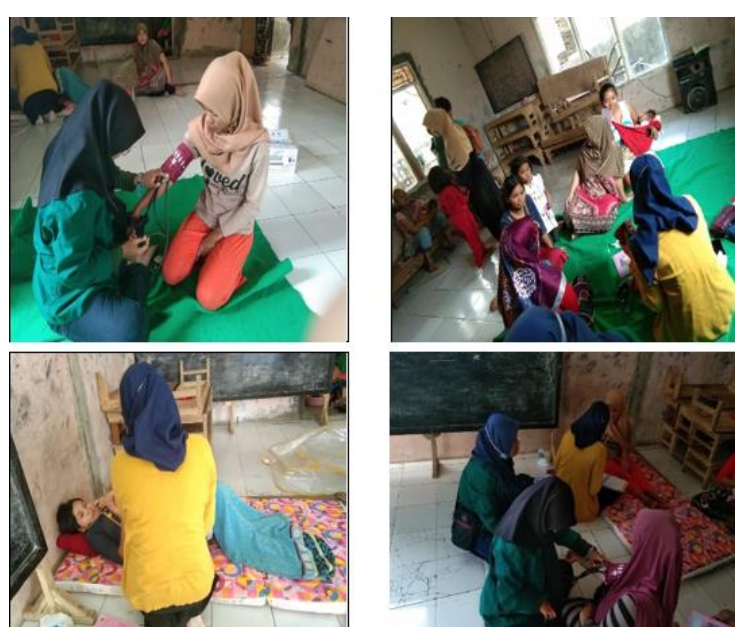

3. Posyandu imunisasi dan Cek Kesehatan Ibu Hamil

Program kerjaPosyandu imunisasi dan Cek Kesehatan Ibu Hamilini dilaksanakan di kampung Cengal RW 10 RT 02 padatanggal 15 Agustus 2019, program yang dilakukan yaitu bekerjasama dengan Posyandu Gelatik dibawah naungan Ibu Neneng dan dibantu oleh Bidan Intan,Am.Keb dengan melakukan cek kehamilan dan cek kesehatan ibu dan anak. Kami membantu Bidan Intan untuk menimbang berat badan anak-anak balita, cek kesehatan ibu hamil dan melakukan pencatatan hasil dari pemeriksaan kehamilan tersebut. Dari hasil pencatatan dan pemeriksaan tersebut dapat dilakukuan penrikan kesimpulan dan dijadikan bahan evaluasi oleh kami dan puskesmas untuk menidaklanjuti keluhan masyarakat serta meningkatkan derajat kesehatannya.
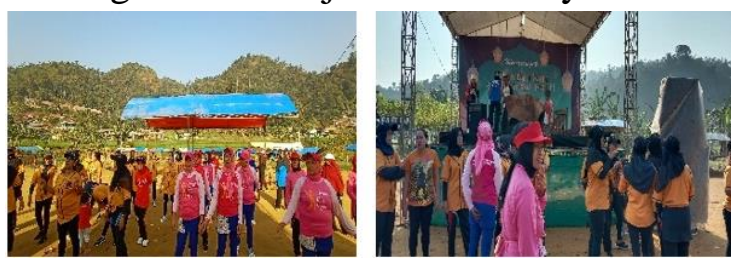

\section{Senam Sehat dan Cek Kesehatan}

Program kerja divisi kesehatan terakhir yang kami lakukan adalah melaksanakan Senam bersama Warga Desa Puraseda di Lapangan Menteng Desa Puraseda pada tanggal 1 September 2019, senam dilaksanakan pada pukul 08.00 WIB 
yang di instrukturi oleh Ibu Caca dan mahasisiwa KKN kelompok 19 \& 20, warga Desa Puraseda sangat berantusias mengikuti senam terutama ibu-ibu dan anak-anak. Senam berakhir pukul 11.00 WIB senam dilakukan bertujuan untuk meningkatkan derajat kesehatan masyarakat serta membantu melancarkan peredaran darah dan membakar kalori dalam tubuh. Dan kemudian dilanjutkan dengan cek kesehatan seperti cek tekanan darah, cek tinggi badan, dan cek berat badan. Program cek tekanan darah pada masyarakat Desa Puraseda dilakukan pada saat usai senam sehat yg dilaksanakan untuk masyarakat desa puraseda. Program ini bertujuan untuk mengetahui tekanan darah pada masyarakat desa purasedakhususnya pada ibu-ibu lansia dan ibu hamil. Dari hasil pemeriksaan tekanan darah terdapat $80 \%$ memiliki tekanan darah diatas 120/80 dan rata-rata menderita tekanan darah tinggi dan merupakan komplikasi hipertensi. Selain itu diadakannya juga konsultasi mengenai keluhan-keluhan masyarakat sehingga nantinya dapat diberikan solusi untuk pemecahan masalah kesehatannya.

\section{BIDANG LINGKUNGAN}

Di dalam bidang lingkungan terdiri dari 6 orang mahasiswa yang berasal dari Fakultas Teknik dan Sains. Kami melakukan 4 program kerja yaitu, Pengolahan Sampah Menjadi Rupiah, Renovasi Sarana Pendidikan, Optimalisasi Potensi Desa, dan Meningkatkan Infrastruktur Desa. Program tersebut kami peroleh setelah melalui metodesurvey pada masyarakat Desa Puraseda dan mendapatkan keresahan yang mengacu pada ke-4 program kerja tersebut.
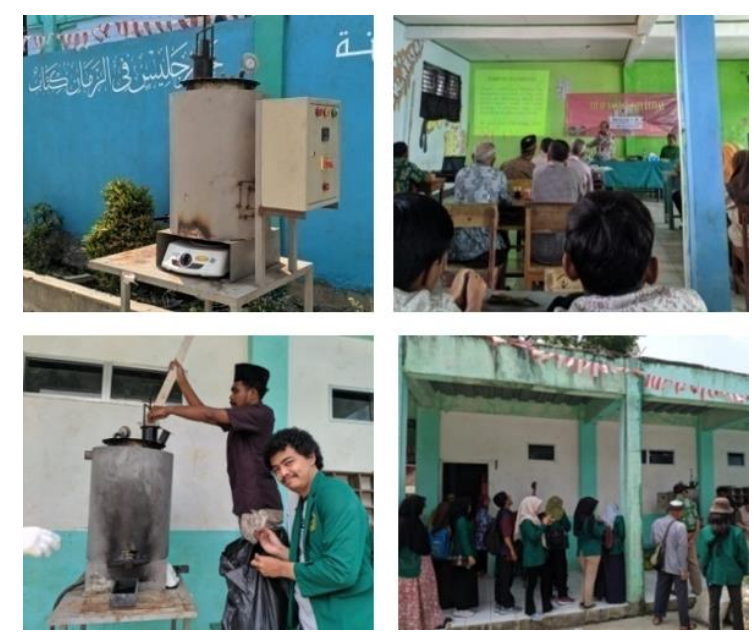

\section{Workshop Pengelolaan Sampah Menajadi Rupiah}

Program Pengolahan Sampah Menjadi Rupiah dilaksanakan berdasarkan data yang didapat dari masyarakat bahwa perilaku membuang sampah di Desa Puraseda masih dilakukan ke sungai terdekat, hal ini dikarenakan tidak adanya lahan pembuangan sampah disekitar rumah mereka dan tidak ada pengangkutan sampah oleh Dinas Kebersihan dan Pertamanan Kabupaten Bogor Jawa Barat. Selain itu, mata pencaharian masyarakat setempat salah satunya penambangan emas ilegal, mengacu pada hal itu kami bermaksud memberikan solusi dengan memanfaatkan sampah plastik yang diolah menjadi paving block. Paving block dibuat dengan cara menggabungkan sampah plastik dengan oli/solar dan dipanaskan dengan suhu kompor yang tinggi, lalu diletakkan ke dalam cetakan berbentuk persegi panjang. Program ini kami realisasikan dengan cara mengadakan workshop di Mts Al Falahiyyah pada tanggal 29 Agustus 2019 dengan Pemateri Widhi Ariyo Bimo, SE., MM. dan Dr. Abdul Karim Halim, M.Si.

Dan puji syukur ada salah seorang Kepala Rukun Tetangga (RT) yang mengikuti workshop ini dan berminat untuk mengembangkan pengolahan 
sampah plastik tersebut di lingkungan RT beliau yang mengikut sertakan warga RT tersebut, sehingga warga RT tersebut tidak lagi membuang sampah ke sungai.
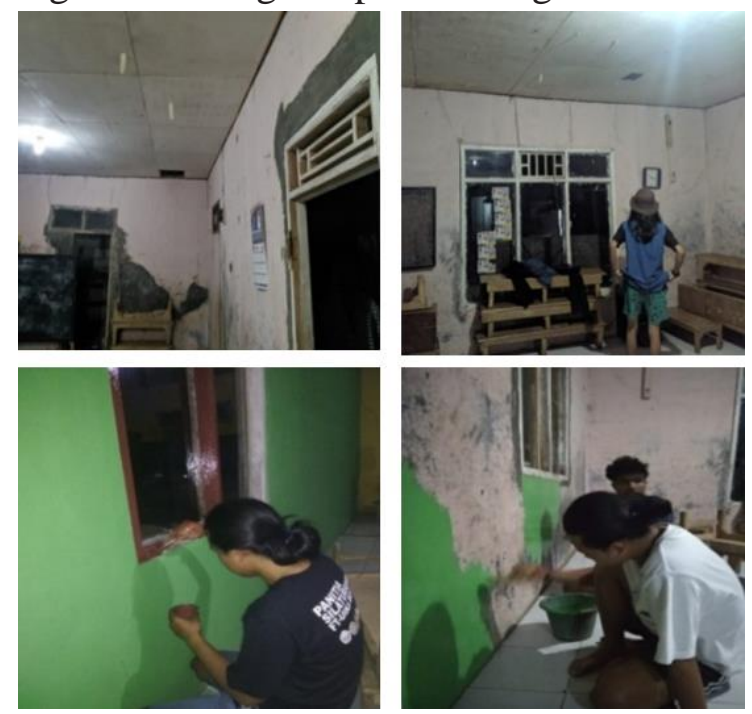

\section{Renovasi Sarana Pendidikan}

Program kerja selanjutnya adalah Renovasi Sarana Pendidikan di PAUD Baitul Hikmah, kegiatan ini dilakukan karena kami mendapati kondisi paud yang kurang terawat. Sedangkan pendidikan usia dini menurut kami sangatlah penting agar anak - anakmenyukai kegiatan belajar hingga berusia dewasa nanti, oleh karena itu kami mengadakan program kerja Renovasi Sarana Pendidikan agar para murid merasa lebih nyaman dalam kegiatan belajar. Program ini kami lakukan selama 2 hari, mulai dari tanggal 31 Agustus - 1 September 2019.
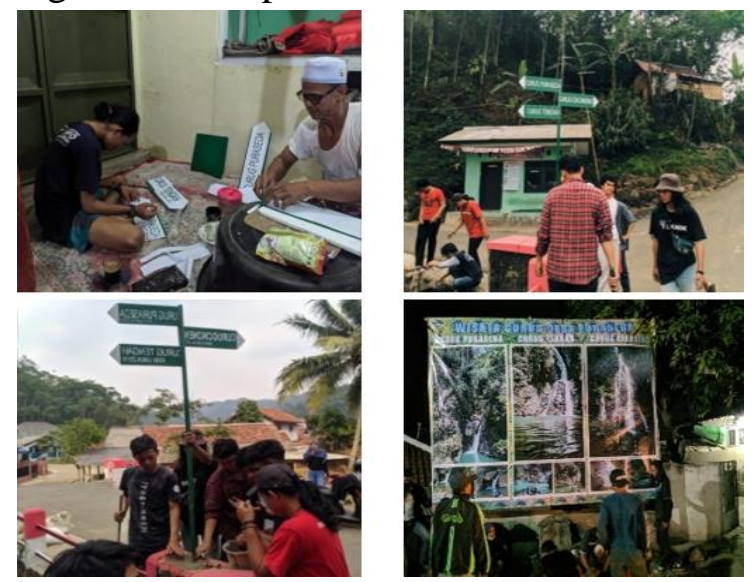

\section{Optimalisasi Potensi Desa}

Program berikutnya adalah Optimalisasi Potensi Desa, diadakannya program ini agar potensi wisata yang ada di Desa Puraseda lebih terpublikasi dan mudah dijangkau oleh masyarakat luas. Di Desa Puraseda terdapat wisata alam berupa air terjun, yaitu air terjun Curug Cikoneng, Curug Puraseda, dan Curug Tengah. Kami membuat petunjuk arah dengan tujuan agar para wisatawan tidak tersesat saat menuju tempat wisata yang ada di daerah Desa Puraseda. Selain itu, kamipun membuat dokumentasi berupa foto, video, dan banner untuk mempublikasikan objek wisata tersebut di jejaring sosial media.
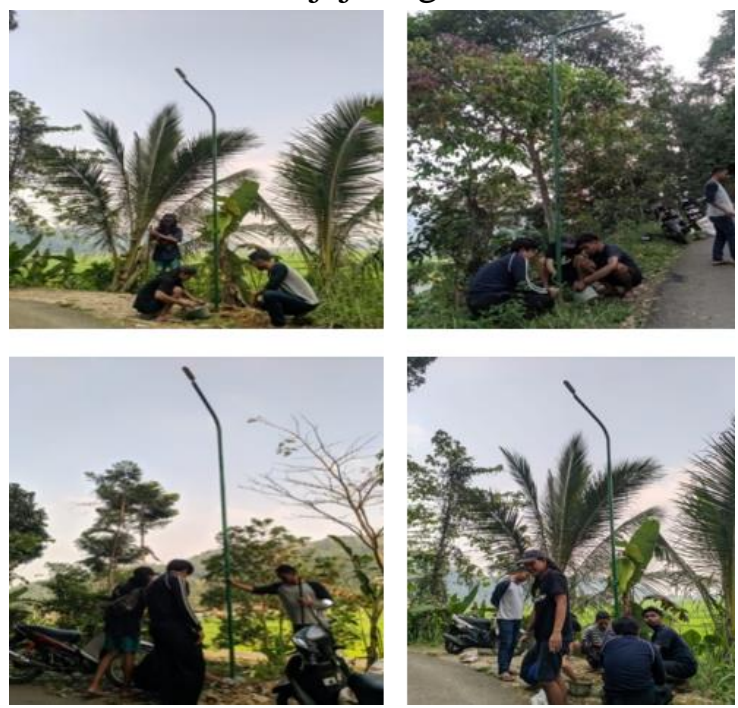

\section{Meningkatkan Infrastuktur Desa}

Program terakhir dari divisi lingkungan ialah Meningkatkan Infrastuktur Desa, setelah dilakukannya tahapan survey kami mendapatkan permasalahan dalam bidang infrastruktur yaitu penerangan jalan umum (PJU) yang kurang dibeberapa titik yang notaben nya terletak di jalan utama Desa Puraseda. Sehingga kami memasang penerangan jalan umum (PJU) dengan menggunakan komponen lampu tenaga panel surya, alasan kami memilih lampu tenaga panel surya agar tidak menggukan listrik dari masyarakat sekitar lampu yang kami dirikan. 


\section{E. BIDANG HUKUM}

\section{Penyuluhan Hukum}

Program Kerja Penyuluhan Hukum Mengenai Surat Kepemilikan Tanah Sebagai Bukti Penguasaan Hak Milik AtasTanah Berdasarkan PP No.24 Tahun 1997 Tentang Pendaftaran Tanah dan Pencatatan Perkawinan.

Kepemilikan sertifikat sebagai bukti penguasaan hak atas tanah telah menjadi hal yang sangat penting untuk terus dilakukan penyuluhan hukum atau sosialisasi ataupun upaya penyadaran terhadap masyarakat. Kepemilikan sertifikat tersebut tidak sekedar terpenuhinya syarat administratif, dan bukti formil saja. Namun lebih dari itu yaitu sebagai jaminan kepastian Hukum. Yang dimaksudkan dengan sertifikat tanah adalah sebagai suatu tanda bukti hak yang berlaku sebagai alat pembuktian yang kuat mengenai data fisik dan data yuridis yang termuat di dalamnya setelah survey di Desa Leuwiliang Bogor masih banyak warga yang tidak mempunyai sertifikat tanah meraka hanya membayar SPPT saja dan hanya mampunyai bukti sertifikat girik atau letter C. Dengan adanya kegiatan pengabdian kepada masyarakat yang dilalukan ini, untuk memunculkan kesadaran masyarakat untuk melakukan pendaftaran tanah, meski pendaftaran tanah bukan merupakan syarat terjadinya jual beli.

Hasil dari kegiatan pengabdian kepada masyarakat ini merupakan salah satu upaya untuk memberikan pengetahuan informasi, pemahaman, dan penyadaran kepada masyarakat mengenai pentingnya kepemilikan sertifikat tanah sebagai bukti penguasaan hak atas tanah. Dalam melakukan pengabdian masyarakat mengenai penyuluhan Hukum pentingnya kepemilikan sertifikat tanah sebagai bukti penguasaan hak atas tanah yang di lakukan di desa Leuwiliang Bogor ini tidak mengalami hambatan yang berarti. Kegiatan ini bertempang di Kantor Kecamatan Leuwiliang Bogor. Pelaksanaan pengabdian ini dilaksanakan pada hari Rabu tanggal 28 Agustus 2019, dengan jumlah peserta 40 (empat puluh orang) yang di hadiri oleh warga desa dan aparatur desa setempat.

Hasil dari kegiatan penyuluhan hukum ini adalah sebagai berikut :

1. Peserta pengabdian merasa antusias terhadap materi yang diberikan oleh penyaji.

2. Terjadi interaksi timbal balik antara peserta dengan penyaji materi.

3. Terjadinya diskusi mengenai materi yang disajikan.

4. Adanya pemahaman, dan kesadaran dari para peserta mengenai pentingnya sertifikat tanah sebagai bukti penguasaan hak atas tanah dan pencatatan perkawinan, sehingga menimbulkan adanya kesadaran untuk melakukan upaya pendaftaran tanah dan pencatatan perkawinan.

Berdasarkan hasil evaluasi, pengamatan dan tanggapan langsung dari peserta kegiatan penyuluhan ini cukup berhasil mengingat adanya peningkatan pemahaman mengenai pentingnya sertifikat tanah sebagai bukti penguasaan hak atas tanah. Pastisipasi dan respon peserta juga terlihat sangat baik, terlihat dari banyaknya tanggapan dan pertanyaan yang diajukan, termasuk dilihat dari jumlah peserta, keaktifan dan diskusi.

Dari temuan yang ada di lapangan, maka perlu kiranya direkomendasikan saran bahwa kegiatan ini dapat dilaksanakan secara terus menerus, agar informasi pemahaman, dan pengetahuan 
masyarakat terhadap pentignya kepemilikan sertifikat sebagai bukti penguasaan hak atas tanah semakin bertambah.

\section{F. PROGRAM TAMBAHAN}
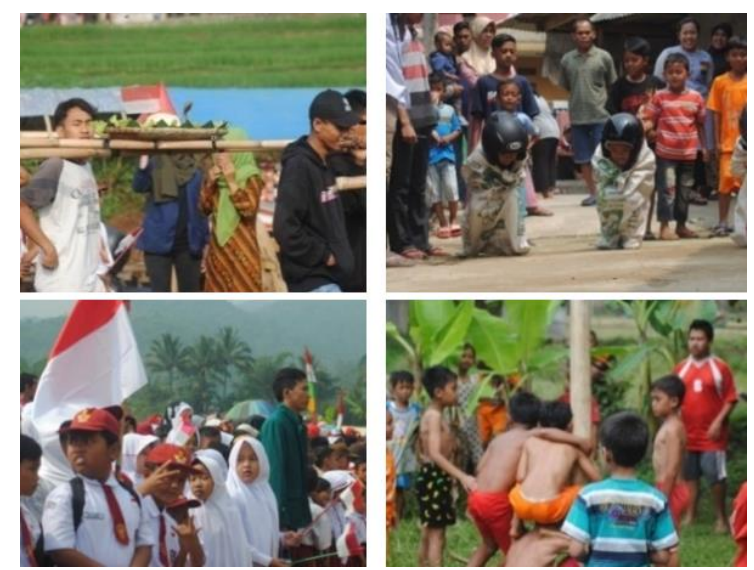

1. Gebyar 17 Agustus 2019

Upacara dilaksanakan di lapangan Cimenteng RW 08 yang dihadiri oleh Kepala desa, Staf desa, para ketua RW dan RT, tenaga pendidik, siswa, mahasiswa dan masyarakat sekitar. Agenda selanjutnya pembagian hadiah lomba yang telah dilaksanakan sebelumnya. Pembagian hadiah diberikan langsung oleh Kepala Desa. Setelah melaksanakan upacara 17 Agustus kami mengadakan berbagai perlombaan, diantaranya : lomba panjat pinang, lomba kerupuk, lomba balap karung helm, koin dalam tepung, estapet tepung, tarik tambang dan lain-lain. Warga sekitar sangat antusias untuk mengikuti perlombaan tersebut. Semoga tahun

\section{KESIMPULAN}

Kuliah Kerja Nyata (KKN) adalah salah satu bentuk pengabdian dari mahasiswa untuk masyarakat. Kami memulai kegiatan pada tanggal 06 Agustus 2019 di Dusun Sabrang Wetan, Desa Puraseda. Desa ini dipimpin oleh kepala desa yaitu H. Awam. Dusun ini termasuk kedalam RW 10 yang terdiri dari empat RT yaitu RT 01, 02, 03, dan 04.Keadaan berikutnya dapat terlaksana kembali dalam memperingati HUT RI.
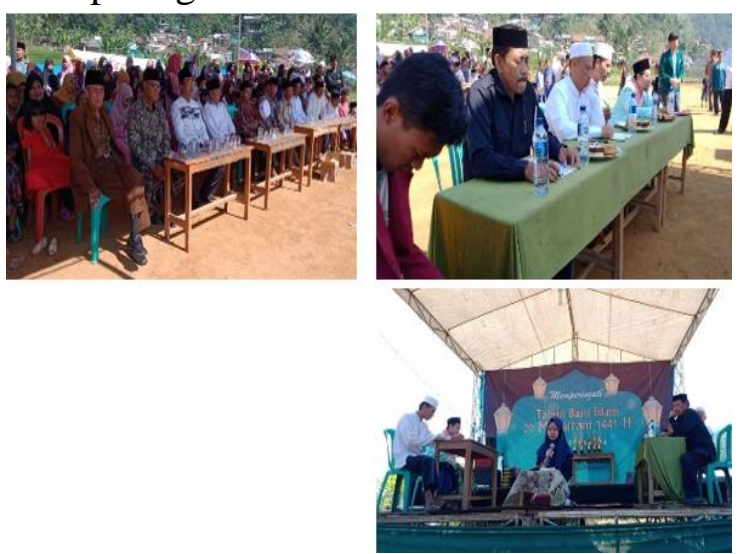

\section{Kegiatan 1 Muharam}

Pelaksanaan 1 Muharam

Agustus 2019) dilaksanakan di lapangan Cimenteng RW 08 yang dihadiri oleh Kepala Desa dan jajarannya serta seluruh warga Desa Puraseda. Pelaksanaan dimulai dari pukul 08.00 - selesai. Dalam acara 1 muharam ini panitia mengadakan beberapa perlombaan, diantaranya : adzan, pildacil, qori', qosidah, pidato. Kemudian pada pukul 20.00 panitia mengadakan acara pawai obor yang dimeriahkan oleh seluruh warga Puraseda yang dimulai dari RW 01 sampai RW 12, titik kumpul pawai obor di lapangan Cimenteng RW 08 yang disambut oleh penampilan hadroh. Kemudian dilanjut dengan sambutansambutan dan pembagian hadiah perlombaan.

wilayah ini termasuk kedalam wilayah yang subur dan banyak pegunungan. Sehingga, mayoritas mata pencaharian warga desa yaitu sebagai petani dan gurandil.

Dari pemaparan program yang ada dapat disimpulkan bahwa program KKN di Desa Puraseda yang telah dijalankan antar lain meliputi program bidang pendidikan, 
bidang ekonomi, bidang kesehatan, bidang hukum dan bidang lingkungan. Program bidang pendidikan antara lain membantu mengajar di SDN Riung Gunung, PAUD Baitul Hikmah, Madrasah Diniyah Siqoyatul Hidayah, Bimbingan Belajar, serta mengadakan pojok baca dan seminar pendidikan untuk para guru yang mengajar tingkat SD, SMP, SMA di Desa Puraseda.

Selanjutnya untuk bidang ekonomi kami memilik program yaitu Gerakan Menabung Sejak Dini, Ekonomi Kreatif, dan Seminar Edukasi Pasar Modal Syariah. Bidang Kesehatan memiliki program PHBS (Perilaku Hidup Bersih dan Sehat), Imunisasi Posyandu dan Cek Kesehatan Ibu Hamil, Senam dan Kerja Bakti. Bidang

\section{SARAN}

1. Masyarakat

a. Masyarakat sebaiknya mengembangkan potensi sumber daya alam yang ada diwilayah Desa Puraseda seperti lahan pertanian yang luas untuk kegiatan pertanian

b. Diperlukan kerjasama antara masyarakat dengan berbagai pihak terkait dengan lembaga pendidikan dan kesehatan karna minat baca anak yang tinggi dan masih minimnya tenaga medis di daerah setempat.

c. Masyarakat harus lebih giat dan berusaha dalam meningkatkan kesejahteraan hidup keluarga
Hukum memiliki program Seminar tentang Penyuluhan Sertifikat Tanah dan Pencatatan Nikah. Pada Bidang Lingkungan kami memiliki program yaitu Workshop Pengelolaan Sampah Menjadi Rupiah, Optimalisasi Potensi Desa, Meningkatkan Infrastruktur Desa, dan Renovasi Sarana Pendidikan. Dari keseluruhan program yang telah dijalankan memilki sasaran seluruh warga Desa Puraseda yang terdiri dari anak-anak hingga orang dewasa khususnya ibu-ibu dan bapak-bapak. Program kerja yang dijalankan oleh kami merupakan program kerja yang telah disusun dan direncanakan terlebih dahulu.

dengan mengembangkan potensi yang ada di Desa.

2. Pemerintah

a. Pemerintah perlu berusaha memfasilitasi keperluan yang dibutuhkan oleh masyarakat dengan pengadaan fasilitas yang lebih memilki manfaat atau guna seperti perlengkapan sarana pendidikan.

Demikian laporan ini kami buat, semoga dapat bermanfaat bagi pihak-pihak yang membutuhkan.Kami mengucapkan terima kasih kepada seluruh pihak yang telah membantu dalam pelaksnaan program KKN Desa Puraseda Universitas Ibn Khaldun Bogor. 


\section{REFERENSI}

Administrasi Profil Desa Puraseda Kecamatan Leuwiliang Kabupaten Bogor Tahun 2017. (Tidak Diterbitkan).

Avessina, M., Kustari, S., \& Anisa, Z., (2018). Pemberdayaan Masyarakat Melalui Komunikasi Penyuluhan. Abdi Dosen: Jurnal Pengabdian Pada Masyarakat, 2(3). Doi: 10.32832/abdidos.v2i3.189.

Bungin, Burhan. (2011). Penelitian kualitatif, Jakarta: Kencana Prenada Media.

Kriyantono, Rachmat. (2006). Riset Komunikasi: Disertai Contoh Praktis Riset Media,Yogyakarta: Kencana Prena Media.

LPPM. (2019). Petunjuk Pelaksanaan Terintegrasi 2019 Universitas Ibn Khaldun Bogor, UIKA PRESS: Bogor.
Muhyani., Rosada, S., \& Sartika, W. (2019). Mengoptimalkan Potensi Sumber Daya Alam Dengan Meningkatkan Kualitas Sumber Daya Manusia Melalui Kepedulian Lingkungan Di Kampung Babakan Inpres Desa Cemplang. Abdi Dosen; Jurnal Pengabdian Pada Masyarakat, 3(1).

Doi:10.32832/abdidos.v3i1.295.

Robert E. Slavin. (2011). Cooperative Learning Teori, Riset Dan Praktik. Bandung: Nusa Media.

Sugiyono. (2016). Metode Penelitian Kuantitatif, Kualitatif, dan $R \& D$. Bandung: ALFABETA.

Syamsuar, F., Alam, A., \& Sari, R (2018). Meningkatkan pendidikan dan pembinaan perilaku hidup bersih dan sehat masyarakat. Abdi Dosen: Jurnal Pengabdian Pada Masyarakat, 2(4).

Doi:

10.32832/abdidos.v2i4.220. 